\title{
Detection of human papilloma virus (HPV) and K-ras mutations in human lung carcinomas
}

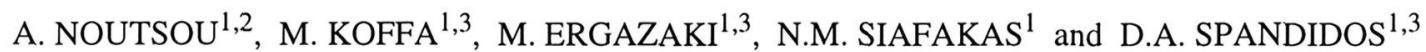 \\ ${ }^{1}$ Medical School, University of Crete, Heraklion; ${ }^{2}$ Department of Pathology, 'Sismanoglion' General Hospital, Athens; \\ ${ }^{3}$ Institute of Biological Research and Biotechnology, National Hellenic Research Foundation, Athens, Greece
}

Contributed by D.A. Spandidos, April 2, 1996

\begin{abstract}
The purpose of our study was to assess the prevalence and prognostic significance of HPV infection as well as K-ras codon 12 point mutations in lung cancer. Patients diagnosed with lung carcinoma between 1988 and $1992(\mathrm{~N}=99)$ were selected. HPV detection and typing was performed by PCR from paraffin-embedded tissues, while mutations in codon 12 of K-ras gene were detected using the restriction fragment length polymorphism (RFLP) analysis. The prevalence of HPV infection was $15 \%$, while $\mathrm{K}$-ras codon 12 point mutations were found in $18 \%$ of the specimens examined. In 50\% of the HPV-positive cases, $\mathrm{K}$-ras gene mutation coexisted. HPV 18 was the most frequent type. No correlation was found between K-ras mutation and HPV infection with sex, age and clinical outcome of the patient, or the histological type and the differentiation grade of the tumor. An association was found between K-ras codon 12 point mutations and the stage of the tumor, occurring more frequently at stage III $(\mathrm{p}=0.037)$. Infection with potentially oncogenic HPV types could co-operate with $\mathrm{K}$-ras gene activation in the progression of the disease, since K-ras activation by point mutations seems to be a late event in lung carcinogenesis.
\end{abstract}

\section{Introduction}

Carcinoma of the lung has become increasingly frequent during the past 50 years. It is now the leading cause of cancer mortality in the Western world. This is due not only to increased recognition through better radiographic, bronchoscopic and cytologic techniques but also to an actual rise in incidence. Carcinoma of the lung is associated with various environmental factors, most importantly smoking and asbestos exposure (1-3). However, many heavy smokers remain free of this disease or other smoking-related cancers. It has been suggested that genetic factors may also contribute to the development of lung carcinoma. So far, no classical linkage analysis that correlates

Correspondence to: Professor D.A. Spandidos, Medical School, University of Crete, Heraklion 71409, Greece

Key words: human papilloma virus (HPV), K-ras oncogene, lung carcinoma incidence of the disease with the inheritance of genetic markers, has been reported for lung cancer (4).

During recent years, a great deal of data has been accumulated on the role of HPV in the development of carcinoma of different anatomical sites of the body. Molecular biology techniques have disclosed that there are at least 73 different types and several subtypes of HPV $(5,6)$. Most viral types are observed in anogenital tract and skin lesions (7). HPV has also been detected in carcinomas of the oral and nasal cavity (8), the male urethra (9), the urinary bladder (1012), the esophagus and the respiratory tract.

With regard to the upper respiratory tract, many types of $\operatorname{HPV}(6,11,16,30)$ have been detected in laryngeal carcinomas $(13,14)$. Clear etiological evidence indicated that in laryngeal papillomas infection with HPV types 16 and 18 was associated with progression to malignant lesions, whereas HPV types $6 \mathrm{~b}$ and 11 were usually associated with benign lesions (15).

In the lower respiratory tract, the causative role of HPV was suggested by morphological data already in 1979: cytological and histological similarities with lesions from uterine cervix condylomas were described in about $30 \%$ of bronchial epithelium next to invasive bronchial squamous cell carcinoma (16) or well differentiated squamous cell carcinoma $(17,18)$. HPV sequences have also been demonstrated in primary lung squamous cell carcinomas (19-21). Patients with squamous cell papillomas exhibiting HPV 16 or 18 positivity are at high risk for the development of squamous cell carcinoma. Virus typing seems to be a better prognostic indicator than grading of dysplasia or age relationship, while virus typing by the PCR is more sensitive compared with in situ hybridization (ISH) (22).

Moreover, molecular tumor markers may offer clinically useful tools for diagnostic and prognostic purposes in lung cancer (23). Ras genes are often found activated in a variety of tumor types, although the incidence varies greatly. K-ras gene is by far the most frequently involved in lung tumors (24-27). Point mutations of the K-ras gene were observed primarily in patients with a habit of smoking. Patients with $\mathrm{K}$-ras positive tumors have a significantly poorer prognosis than patients with $\mathrm{K}$-ras negative tumors (28). There is evidence that $\mathrm{K}$-ras gene may serve as a genetic marker not only in the early detection of lung cancer (29) but also in the differential diagnosis of recurrence or metastasis versus second primaries of the lung (30). In addition strong overexpression of K-ras gene has been reported in a high incidence of non-small cell lung carcinomas (31). 
In the current study, HPV detection and typing as well as detection of K-ras gene mutations was performed in 99 cases of lung carcinoma from paraffin-embedded tissues employing the PCR technique. $15 \%$ of the specimens were found positive for HPV, while $18 \%$ carried mutation in the codon 12 of the $\mathrm{K}$-ras gene. It was also examined whether such alterations correlate with clinicopathological parameters or clinical outcome.

\section{Materials and methods}

Patients and specimens. The primary neoplasm specimens were excised either by surgical lobectomy or pneumonectomy and fixed in neutral formalin, at Sismanoglion General Hospital, Athens, between 1988-1992. Hematoxylin-eosin stained sections from all paraffin-embedded tissues examined, were reviewed to reconfirm the tumor type, differentiation grade while representative blocks (one per case) were selected for further analysis.

Eighty-seven of the 99 patients were smokers, 3 were nonsmokers and for the remaining 9 no reliable data on smoking habits were available. Most of the smokers were heavy smokers (>60 py). The age range was $44-77$ years, and the mean age 62.8 years.

DNA extraction. Five or six $10 \mu \mathrm{m}$ thick sections from formalinfixed, paraffin-embedded tissues were lysed in $400 \mu$ ldigestion buffer, containing $100 \mathrm{mM} \mathrm{NaCl}, 10 \mathrm{mM}$ Tris-HCl, $25 \mathrm{mM}$ EDTA, $0.5 \%$ SDS pH 8.0, $0.1 \mathrm{mg} / \mathrm{ml}$ proteinase K. Samples were incubated for $24 \mathrm{~h}$ at $37^{\circ} \mathrm{C}$. Fresh proteinase $\mathrm{K}$ was added and the incubation was continued for another $24 \mathrm{~h}$. The samples were then extracted once with phenol/chloroform and once with chloroform. DNA was precipitated with the addition of $20 \mu \mathrm{M} \mathrm{N} \mathrm{NaCl}$ and $1 \mathrm{ml}$ ethanol, recovered by centrifugation for $15 \mathrm{~min}$ at $4^{\circ} \mathrm{C}$, washed once with cold $70 \%$ ethanol and resuspended in $30 \mu \mathrm{l}$ double distilled water.

Oligonucleotide primers and PCR amplification. For the detection and type distinction of the HPV, multiplex PCR was employed using four pairs of primers stimultaneously (for HPV types 11, 16, 18 and 33), providing different lengths of amplified DNA for each virus type (32), while the results were confirmed using the general primers GP5 and GP6 (33) followed by RsaI digestion giving a different pattern for each type (34). The oligonucleotides used for K-ras have been previously described (35). One $\mu 1$ of the extracted DNA of each sample was amplified in a reaction solution of $50 \mu \mathrm{l}$ containing $20 \mathrm{mM}\left(\mathrm{NH}_{4}\right)_{2} \mathrm{SO}_{4}$, $2.0 \mathrm{mM} \mathrm{MgCl}$, $75 \mathrm{mM}$ Tris- $\mathrm{HCl} \mathrm{pH} \mathrm{9.0,0.01 \%} \mathrm{(w/v)} \mathrm{Tween,}$ $200 \mu \mathrm{M}$ of each dNTP, $0.5 \mu \mathrm{M}$ of each primer and 1.25 U Taq polymerase (Advanced Biotechnologies). The mixture was heated for $1 \mathrm{~min}$ at $95^{\circ} \mathrm{C}$, and then subjected to 35 cycles of amplification under the following conditions.

HPV amplification: Using the specific set of primers each cycle consisted of $50 \mathrm{sec}$ at $94^{\circ} \mathrm{C}, 40 \mathrm{sec}$ at $56^{\circ} \mathrm{C}$ and $45 \mathrm{sec}$ at $72^{\circ} \mathrm{C}$, increasing the elongation time $1 \mathrm{sec}$ per cycle. To establish type specificity of primer-directed amplification, each set of primers was tested with template plasmid DNA of the five HPV types 6b, 11, 16, 18 and 33 .

Using the general primers GP5 and GP6 each cycle consisted of $50 \mathrm{sec}$ at $94^{\circ} \mathrm{C}, 50 \mathrm{sec}$ at $52^{\circ} \mathrm{C}$ and $40 \mathrm{sec}$ at $72^{\circ} \mathrm{C}$, increasing the elongation time $1 \mathrm{sec}$ per cycle.
K-ras amplification: Each cycle consisted of a denaturation step at $94^{\circ} \mathrm{C}$ for $50 \mathrm{sec}$, an annealing step at $58^{\circ} \mathrm{C}$ for $45 \mathrm{sec}$ and an elongation step at $72^{\circ} \mathrm{C}$ for $50 \mathrm{sec}$, increasing the elongation time $1 \mathrm{sec}$ per cycle.

RFLP analysis. HPV-general primers: Confirmation of the typing was achieved by digestion of the amplification products with $30 \mathrm{U}$ of RsaI giving a different pattern for each type. Digestion products were electrophoresed through a $10 \%$ polyacrylamide gel. As control the amplified product of plasmid DNA of the HPV types 6b, 11, 16, 18 and 33 were used.

$\mathrm{K}$-ras: $10-20 \mu \mathrm{l}$ were digested for $3 \mathrm{~h}$ with $30 \mathrm{U}$ of BstNI. Digestion products were electrophoresed through an $8 \%$ polyacrylamide gel. Gels were stained with ethidium bromide and photographed on a UV light transilluminator. Enzymes were supplied by New England Biolabs and the conditions followed for digestions were those recommended by the supplier. Incubation temperatures were $37^{\circ} \mathrm{C}$ for RsaI and $60^{\circ} \mathrm{C}$ for BstNI.

Statistical analysis. The presence of HPV and mutations at codon 12 of $\mathrm{K}$-ras gene were analysed for significant correlation with histological type, grade, TNM stage and age at day of operation, by Fisher's exact test. Survival curves were drawn up using the Kaplan-Meier method. Differences between survival times were analysed by the log rank method.

\section{Results}

In the current study we examined 99 specimens from patients with lung carcinomas. Tumors were classified according to their histological type: 41 adenocarcinomas, 41 squamous cell, 10 undifferentiated large cell, 5 small cell and 2 adenosquamous carcinomas. According to the degree of histological differentiation: 7 well, 42 moderate and 33 poorly differentiated carcinomas. Tumors were also staged according to the TNM system as: 46 in stage I, 37 in stage II and 16 in stage III. Follow-up was available for 42 patients. 32 have died of the disease while 10 patients are still alive (after 1-63 months following surgery). Although no statistically significant correlations were found, the survival was shorter in patients with ras mutations (average survival 665.1 days), HPV infection (a.s. 718.2 days) and HPV infection simultaneously with ras mutations (a.s. 773.1 days), compared to those with no such alterations (a.s. 929.7, 956.7 and 871.2 days respectively).

The type of HPV as well as the presence of point mutations in codon 12 of the K-ras gene were examined. The results of the PCR analysis are summarized in Table I.

Fifteen of the 99 specimens (15\%) were found positive for HPV. The prevalence of HPV infection was $20 \%$ in adenocarcinomas, $9.7 \%$ in squamous cell carcinomas, $20 \%$ in undifferentiated large cell carcinomas, while HPV was also found in one of the two adenosquamous carcinomas. Results from the type distinction of HPV (Fig. 1) indicated that HPV 18 was the most frequent type (in $8 \%$ of the cases), while HPV 16 was found in 4\%, HPV 11 in 3\% and HPV 33 in $2 \%$ of the cases examined (Table II). Samples found positive with the multiplex PCR (amplifying a region from the E6 ORF) were also positive with the general primer PCR, indicating that the $\mathrm{L} 1$ region was present. 
Table I. Detection of HPV and K-ras codon 12 point mutations in lung carcinomas by PCR.

\begin{tabular}{lcccc}
\hline \multicolumn{1}{c}{$\begin{array}{c}\text { Histological } \\
\text { type }\end{array}$} & $\begin{array}{c}\text { No. of } \\
\text { patients }\end{array}$ & $\begin{array}{c}\text { HPV } \\
\text { positive }(\%)\end{array}$ & $\begin{array}{c}\text { K-ras } \\
\text { mutations (\%) }\end{array}$ & $\begin{array}{c}\text { HPV+K-ras } \\
(\%)\end{array}$ \\
\hline Adenocarcinoma & 41 & $8(20)$ & $8(20)$ & $4(9.8)$ \\
Squamous cell carcinoma & 41 & $4(9.8)$ & $7(17)$ & $3(7.3)$ \\
Undifferentiated large cell carcinoma & 10 & $2(20)$ & $2(20)$ & 1 \\
Small cell carcinoma & 5 & 0 & 0 & 0 \\
Adenosquamous carcinoma & 2 & 1 & 1 & 1 \\
Total & 99 & $15(15)$ & $18(18)$ & $9(9.1)$ \\
\hline
\end{tabular}

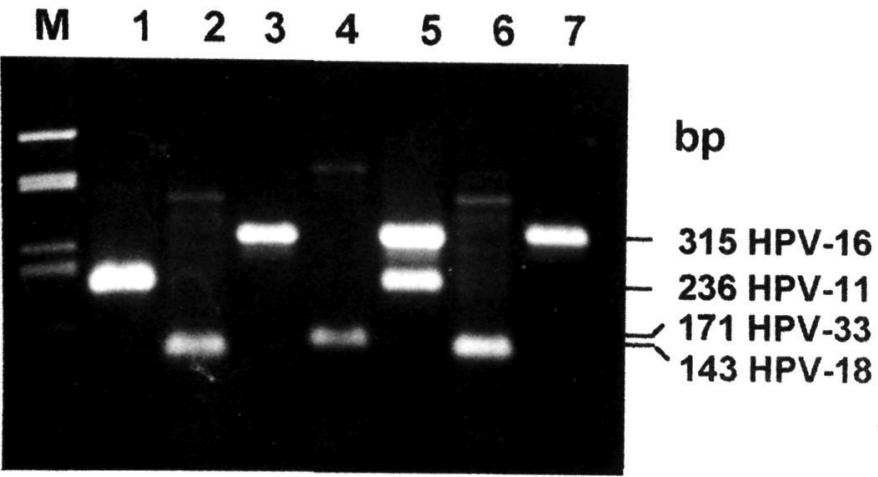

Figure 1. Type distinction of HPV employing a multiplex PCR. Products of different size (315 bp, HPV 16; 236 bp, HPV 11; 171 bp, HPV33; and 143 bp, HPV 18) were analysed by agarose gel electrophoresis. Lane M, molecular weight marker pUC18/HaeIII; lane 1, sample positive for HPV 11; lanes 2,6, samples positive for HPV 18; lanes 3,7, samples positive for HPV 16; lane 4, sample positive for HPV 33; lane 5, sample positive for HPV 16HPV 11.

Table II. Incidence of HPV type in primary lung carcinomas.

\begin{tabular}{lc}
\hline Type of HPV & HPV positive carcinomas \\
\hline HPV 18 & 8 \\
HPV 16 & 4 \\
HPV 11 & 3 \\
HPV 33 & 2 \\
\hline
\end{tabular}

ain a total of 99 samples.

$\mathrm{K}$-ras codon 12 point mutations were found in 18 of the 99 specimens (18\%) examined (Fig. 2). Mutations were found in $8(20 \%)$ of the 41 cases of adenocarcinoma, in $7(17 \%)$ of the 41 cases of squamous cell carcinoma, in $2(20 \%)$ of the 10 cases of undifferentiated large cell carcinoma and in 1 of the 2 cases of adenosquamous carcinoma.

The simultaneous presence of HPV DNA and K-ras mutation was observed in almost $50 \%$ of the HPV positive cases: in $9.8 \%$ of adenocarcinomas, in $7.3 \%$ of squamous cell carcinomas, in $10 \%$ of undifferentiated large cell carcinomas and in one of the two adenosquamous carcinomas.

No correlation was found between HPV infection and K-ras mutation either with sex and age of the patient, or the histological type and the differentiation grade of the tumor. Survival curves

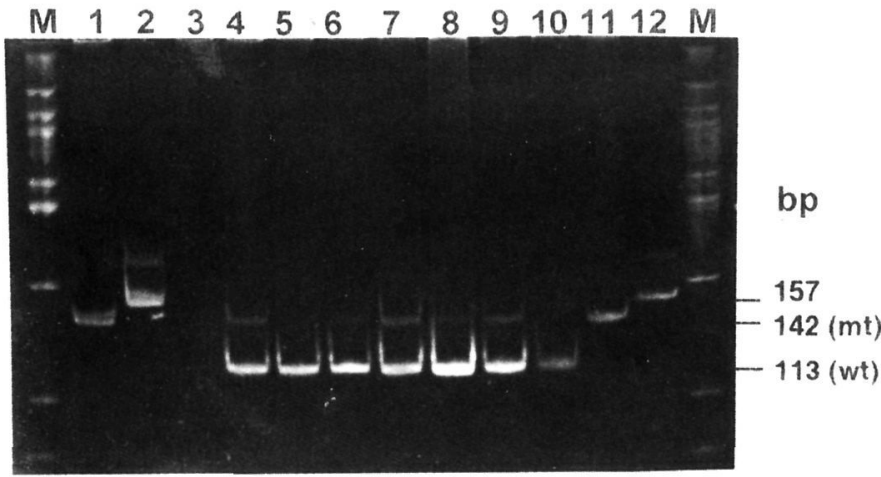

Figure 2. K-ras amplification products (157 bp) were digested with the restriction endonuclease BstNI and electrophoresed through an $8 \%$ polyacrylamide gel. Lanes $\mathrm{M}$, molecular weight marker pUC18/HaeIII; lanes 1,11, positive control SW480 cell line (142 bp); lanes 2,12, undigested PCR product; lane 3, negative control; lanes 4,7-9, positive samples; lanes $5,6,10$, negative samples (113 bp).

determined by Kaplan-Meier method demonstrated that HPV infection and codon 12 point mutation of K-ras gene did not correlate with the clinical outcome of the patients. An association was found between K-ras codon 12 point mutations and the stage of the tumor, occuring more frequently at stage III $(p=0.037)$ than stage I. These data suggest that infection with potentially oncogenic HPV types could be associated not only with anogenital tumors, but also with a subset of lung tumours, while HPV could co-operate with K-ras mutations in the progression of the disease.

\section{Discussion}

The potential role of HPV in the development of lung carcinomas emerged after the description of condylomatouslike lesions in the bronchial epithelium adjacent to squamous cell carcinomas. Intranuclear HPV-like particles were demonstrated by electron microscopy in squamous cell papillomas of the bronchus (36).

The presence of HPV in lung carcinomas has been reported in several studies. The rate of positivity varied between $4.2 \%$ and $31 \%(19-21)$, while in carcinomas with condylomatous changes the rate was higher (42\%) (20). In contrast other investigators reported absence of HPV in lung cancer $(37,38)$, this divergence may be due to the differences in the sensitivity and specificity of the methods applied, as well as to epidemio- 
logical factors. In the current study we confirm the presence of HPV in lung carcinomas, using primers from both the E6 and L1 ORFs. The use of primers located in the E6 ORF, which remains intact in the case of high risk HPV type integration into the host genome, allows better diagnostic sensitivity. No difference was found in the detection rate of the virus using the two sets of primers from the E6 and L1 ORFs.

It is noteworthy that HPV was also detected in cases of adenocarcinoma. Recently, there has been increasing interest in the association between HPV and glandular neoplasia. In many studies HPV DNA has been found in adenocarcinomas and adenosquamous carcinomas as frequently as in squamous cell carcinomas of the cervix (39-41).

In our study we found that multiple subtypes of HPV may be related to lung cancer. However HPV 18 was the predominant type, which is in agreement with other studies reporting that high-risk HPV types were more frequently detected $(19,20,22)$. Their identification in both squamous cell carcinomas and adenocarcinomas as well as in adenosquamous and undifferentiated large cell carcinomas suggests a key role in the process of lung carcinogenesis. Moreover, it has been suggested that infection with high risk HPVs could serve as a prognostic indicator of malignant progression in lung squamous cell papillomas (22).

Multiple molecular changes have also been documented in lung cancer. These include activation of dominant oncogenes, such as the ras gene family (23), myc and HER-2/neu genes, as well as loss of recessive growth regulatory genes, or onco-suppressor genes (p53, rb) $(23,26)$.

Several studies have reported an incidence of $15-33 \%$ of activated K-ras gene in lung carcinomas, while more recent studies have revealed a higher incidence of more than 50\% (42-44). In the current study we found K-ras codon 12 point mutations in $18 \%$ of the specimens examined. In cases of squamous cell carcinomas the incidence of K-ras mutations was higher than in other studies $(24,42)$, propably due to the more sensitive assay used. Activation of the K-ras gene was examined, since point mutations of this member of the ras family are found more commonly in lung cancer and occur predominantly at codon 12 .

It has been suggested that K-ras mutations arise predominantly at the non-invasive stage of lung carcinogenesis, and may be associated with the transformation of dysplastic cells to neoplastic (45). Moreover, detection of K-ras mutations in sputum may precede diagnosis of lung cancer (29). On the other hand, a significant number of lung adenocarcinomas harbor ras mutations in only a small percentage of the cancer cells, indicating that $\mathrm{K}$-ras mutations represent a late event in lung carcinogenesis (23). This concept is consistent with the association of ras mutations with increased tumor growth and invasiveness, as suggested by the poorer prognosis of mutationpositive than mutation-negative cases treated by surgical resection $(44,46)$. We found an association between K-ras mutations and the stage of the tumor, occuring more frequently at cases with stage III. However, no correlation was found between $\mathrm{K}$-ras mutations and the clinical outcome of the patients examined. In $50 \%$ of the HPV-positive cases, K-ras mutation co-existed. This might suggest that HPV infection is not sufficient by itself for malignant transformation, but requires co-operation of an activated ras gene. In addition, carcinogen exposure may induce transformation in several fields of the bronchial epithelium through the induction of different genetic changes.

Our results indicate that HPV infection and K-ras gene activation may play a role in a subset of lung tumors. The possibility of synergic mechanisms between HPV, ras gene mutations and chemical or physical carcinogens such as cigarette smoking should also be considered.

\section{References}

1. Loeb LA, Ernster VL, Warner KE, Abbotts $\mathrm{J}$ and Laszio J: Smoking and lung cancer: an overview. Cancer Res 44: 5940-5958, 1984.

2. Kvale G, Bjelke E and Heuch I: Occupational exposure and lung cancer risk. Int J Cancer 37: 185-193, 1986.

3. Selikoff IJ, Hammond EC and Chyrg J: Asbestos exposure, smoking and neoplasia. JAMA 204: 106-112, 1968.

4. Rabbitts PH: Genetic changes in the development of lung cancer. Br Med Bull 50: 688-697, 1994.

5. zur Hausen $\mathrm{H}$ and de Villiers EM: Human papillomaviruses. Annu Rev Microbiol 48: 427-447, 1994.

6. Vousden KH: Viruses and human cancer. Br Med Bull 50: 560-581, 1994

7. zur Hausen $\mathrm{H}$ : Human papillomavirus in the pathogenesis of anogenital cancer. Virology 184: 9-13, 1991.

8. Furuta Y, Takasu T, Asai T, Shinohara T, Sawa H, Nagashima K and Inuyama Y: Detection of human papillomavirus DNA in carcinomas of the nasal cavities and paranasal sinuses by polymerase chain reaction. Cancer 69: 353-357, 1992.

9. Wiener JS, Liu ET and Walther PJ: Oncogenic human papillomavirus type 16 is associated with squamous cell cancer of the male urethra. Cancer Res 52: 5018-5023, 1992.

10. Anwar K, Naiki H, Nakakuki K and Inzuzuka M: High frequency of human papillomavirus infection in carcinoma of the urinary bladder. Cancer 70: 1967-1973, 1992.

11. Noel JC, Thiry L, Verhest A, Deschepper N, Peny MO, Sattar AA, Schulman CC and Haot J: Transitional cell carcinoma of the bladder evaluation of the role of human papillomaviruses. Urology 44: 671-675, 1994

12. Maloney $\mathrm{K}$, Wiener $\mathrm{H}$ and Walter $\mathrm{PH}$ : Oncogenic human papillomaviruses are rarely associated with squamous cell carcinoma of the bladder: evaluation by differential polymerase chain reaction. J Urol 154: 360-364, 1994.

13. Hoshikawa T, Nakajima T, Uhara $\mathrm{H}$, Gotoh $\mathrm{M}$, Shimosato $\mathrm{Y}$, Tsutsumi K, Ono I and Ebihara S: Detection of human papillomavirus DNA in laryngeal squamous cell carcinomas by polymerase chain reaction. Laryngoscope 100: 647-650, 1990.

14. Perez-Ayala M, Ruiz-Cabello F, Esteban F, Concha A, Redondo M, Oliva MR, Cabrera T and Garrido F: Presence of HPV 16 sequences in laryngeal carcinomas. Int J Pathol 46: 8-11, 1990.

15. McCance DJ: News on papillomaviruses. Nature 335: 765-766, 1988.

16. Syrjänen KJ: Condylomatous changes in neoplastic bronchial epithelium: report of a case. Respiration 98: 299-304, 1979.

17. Syrjänen KJ: Bronchial squamous cell carcinomas associated with epithelial changes identical to condylomatous lesions of uterine cervix. Lung 158: 131-142, 1980.

18. Syrjänen KJ: Epithelial lesions suggestive of a condylomatous origin found closely associated with invasive bronchial squamous cell carcinomas. Respiration 40: 150-160, 1980.

19. Yousem SA, Ohori NP and Sonmez-Alpan E: Occurence of human papillomavirus DNA in primary lung neoplasms. Cancer 69: 693-697, 1992.

20. Bejui-Thivolet F, Liagre N, Chignol M, Chardonnet $Y$ and Patricot L: Detection of human papillomavirus DNA in squamous bronchial metaplasia of the lung by in situ hybridization using biotinylated probes in paraffin-embedded specimens. Hum Pathol 21: 111-116, 1990.

21. Bejui-Thivolet F, Chardonnet $Y$ and Patricot L: Human papillomavirus type 11 DNA in papillary squamous cell lung carcinoma. Virchows Arch (A) 417: 457-461, 1990.

22. Popper HH, El-Shabrawi Y, Wöckel W, Höfler G, Kenner L, Freya, Juttner-Smole and Pongratz MG: Prognostic importance of human papillomavirus typing in squamous cell carcinoma of the bronchus. Hum Pathol 25: 1191-1197, 1994. 
23. Anderson MLM and Spandidos DA: Oncogenes and oncosuppressor genes in lung cancer. Resp Med 87: 413-420, 1993.

24. Kiaris H and Spandidos DA: Mutations of ras genes in human tumours (review). Int J Oncol 7: 413-421, 1995.

25. Neville EM, Ellison G, Kiaris H, Stewart M, Spandidos DA and Field JK: Detection of K-ras mutations in non-small cell lung carcinoma. Int J Oncol 7: 511-514, 1995.

26. Kiaris H, Ergazaki M, Sakkas S, Athanasiadou E and Spandidos DA: Detection of activating mutations in the ras family gene in cytological specimens from lung tumours. Oncol Rep 2: 769-772, 1995

27. Mills NE, Fishman CL, Rom WN, Dubin N and Jacobson DR: Increased prevalence of K-ras oncogene mutations in lung adenocarcinoma. Cancer Res 55: 1444-1447, 1995.

28. Slebos RJ, Kibbelaar RE, Dalesio O, Kooistra A, Stam J, Meijer CJ, Wagenaar SS, Vanderschueren RG, van Zandijk N, Mooi WJ, Bos JL and Rodenhuis S: K-ras oncogene activation as a prognostic marker in adenocarcinoma of the lung. $\mathrm{N}$ Engl $\mathrm{J}$ Med 323: 561-565, 1990

29. Mao L, Hruban H, Boyle JO, Tockman M and Sidransky D: Detection of oncogene mutations in sputum precedes diagnosis in lung cancer. Cancer Res 54: 1634-1637, 1994.

30. Sozzi G, Miozzo M, Pastorino U, Pilotti S, Donghi R, Giarola M, De-Gregorio L, Manenti G, Radice P, Minoletti F, Della Porta G and Pierotti MA: Genetic evidence for an independent origin of multiple preneoplastic and neoplastic lung lesions. Cancer Res 55: 135-140, 1995.

31. Lorenz J, Friedberg T, Oesch F and Ferlinz R: Oncogene overexpression in non-small cell lung cancer tissue: prevalence and clinicopathological significance. Clin Investigator 72: 156-163, 1994.

32. Arends MJ, Donaldson YK, Duvall E, Wyllie AH and Bird CC: HPV in full thickness cervical biopsies: high prevalence in CIN 2 and CIN 3 detected by a sensitive PCR method. J Pathol 165: 301-309, 1991.

33. Snijders PJF, van den Brule AJC, Schrijnemakers HFJ, Snow G, Meijer CJLM and Walboomers JMM: The use of general primers in the polymerase chain reaction permits the detection of a broad spectrum of human papillomavirus genotypes. J Gen Virol 71: 173-181, 1990.

34. Koffa M, Koumantakis E, Ergazaki M, Malamou-Mitsi V and Spandidos DA: Detection of ras gene mutations and HPV in lesions of the human female reproductive tract. Int J Oncol 5: 189-195, 1994.

35. Spandidos DA, Liloglou T, Arvanitis D and Gourtsoyiannis NC: Ras gene activation in human small intestinal tumors. Int $\mathrm{J}$ Oncol 2: 513-518, 1993.
36. Brandwein M, Steinberg B, Thung S, et al: Human papillomavirus $6 / 11$ and $16 / 18$ in Schneiderian inverted papillomas. In situ hybridization with human papillomavirus RNA probes. Cancer 63: 1708-1713, 1989.

37. Szabo I, Sepp R, Nakamoto K, Maeda M, Sakamoto H and Uda H: Human papillomavirus not found in squamous and large cell lung carcinomas by polymerase chain reaction. Cancer 73: 2740-2744, 1994.

38. Shamanin V, Delius H and de Villiers EM: Development of a broad spectrum PCR assay for papilloma viruses and its application in screening lung cancer biopsies. J Gen Virol 75: 1149-1156, 1994.

39. Cooper K, Herrington CS, Evans MF and McGee JOD: Integration of human papillomavirus types 16 and 18 in cervical adenocarcinoma. J Clin Pathol 45: 382-384, 1992.

40. Johnson TL, Kim W, Plieth DA and Sarkar FH: Detecion of HPV 16/18 in cervical adenocarcinoma using polymerase chain reaction methodology. Modern Pathol 5: 35-40, 1992.

41. Duggan MA, Benoit JL, McGregor SE, Nation JG, Inoue M and Stuart GCE: The human papillomavirus status of 114 endocervical adenocarcinoma cases by dot blot hybridization. Hum Pathol 24: 121-125, 1993

42. Li S, Rosell R, Urban A, Fontan A, Ariza A, Armengol P, Abad A, Navas JJ and Monzo M: K-ras gene point mutation: a stable tumor marker in non-small cell lung carcinoma. Lung Cancer 11: 19-27, 1994

43. Mitsudomi T, Viallet J, Mulshine JL, Linnoila RI, Minna JD and Gazdar AF: Mutations of ras genes distinguish a subset of non-small cell lung cancer cell lines from small-cell lung cancer cell lines. Oncogene 6: 1353-1362, 1991.

44. Sugio K, Ishida T, Yokoyama H, Inoue T, Sugimachi K and Sadazuki T: ras gene mutations as a prognostic marker in adenocarcinoma of the human lung without lymph node metastasis. Cancer Res 52: 2903-2906, 1992.

45. Sugio K, Kishimotto Y, Virmani AK, Hung JY and Gazdar AF: $\mathrm{K}$-ras gene mutations are a relatively late event in the pathogenesis of lung carcinomas. Cancer Res 54: 5811-5815, 1994.

46. Mitsudomi T, Steinberg SM, Oie HK, Mulshine JL, Phelps R, Viallet J, Pass H, Minna JD and Gazdar AF: ras gene mutations in non-small lung cancers are associated with shortened survival irrespective of treațment intent. Cancer Res 51: 4999-5002, 1991. 